\title{
Comparison of toric intraocular lens implantation, limbal relaxing incisions and opposite clear corneal incision for management of co-existing astigmatism on cataract surgery
}

\author{
Katarakt cerrahisinde astigmatizmanın düzeltilmesinde torik intraoküler \\ lens implantasyonu, limbal gevşetici insizyon ve karşılıklı saydam korneal \\ kesi yöntemlerinin karşılaştırılması
}

Işılay ÖZSOY KOYUN ${ }^{1} \oplus$, Hacı Uğur ÇELiK ${ }^{2}$, Hüseyin BAYRAMLAR ${ }^{3}$, Efe KOYUN ${ }^{1}$

\section{ABSTRACT}

Aim: To compare the efficacy and visual outcomes of toric intraocular lenses, limbal relaxing incisions and opposite clear corneal incisions for management of coexisting astigmatism in cataract surgery.

\begin{abstract}
Methods: In this retrospective comparative study files of 56 patients who underwent phacoemulsification with either Toric IOL or monofocal IOL with LRI or monofocal IOL with OCCI for their 56 eyes with visually significant cataract and coexisting corneal astigmatism were investigated. The main outcome measures were postoperative 6-month best corrected visual acuity, changes in cylindrical and keratometer value.
\end{abstract}

Results: Best corrected visual acuities at sixth months were better at a statistically significant level in three groups compared to the baseline measurements $(p<0.01, p<0.01, p<0.01)$. The mean refractive astigmatism values were preoperatively $2.92 \pm 1.1$ in the $L R I$ group, $2.46 \pm 1.7$ in the OCCl group, $2.68 \pm 0.90$ in the toric group whereas postoperatively they were $1.01 \pm 0.61,1.16 \pm 1.12$ and $0.9 \pm 0.8 D$ respectively $(p<0.01, p<0.01, p<0.01)$. Corrected degrees of astigmatism were $1.9 \pm 1.1$ for the $L R I$ group, $1.3 \pm 1.2$ for the OCCl group and $1.78 \pm 0.90$ dioptry for the toric group. The difference among three groups was not statistically significant.

Conclusion: An increase in the BCVA value and a decrease in refractive astigmatism were detected postoperatively in all groups. Although the most prominent improvement in refractive astigmatism occurred in the LRI group, there was no significant difference among the groups.

Keywords: Astigmatism, limbal relaxing incision, opposite clear corneal incision, toric intraocular lens, cataract
Öz

Amaç: Astigmatizması olan katarakt cerrahisi olgularında torik göz içi lensleri, limbal gevşetici kesi ve karşılıklı saydam korneal kesi uygulamalarının etkinliğini ve görsel sonuçlarını karşılaştırmak.

Yöntem: Bu retrospektif karşılaştırmalı çalışma görsel olarak anlamlı kataraktı ve eşlik eden astigmatizması olan 56 hastanın 56 gözüne fakoemülsifikasyon uygulanıp, torik göz içi lensi veya monofokal göz içi lensi ile birlikte limbal gevşetici insizyon (LRI) veya monofokal göz içi lensi ile birlikte karşılıklı saydam korneal insizyon (OCCI) uygulanan hastaların dosyaları incelenerek yapıldı. Başlıca sonuç kriterleri postoperatif 6 aylık düzeltilmiş görme keskinliği, silindirik ve keratometre değer değişimleri idi.

Bulgular: Altıncı ayda düzeltilmiş görme keskinlikleri başlangıç ölçümlerine göre 3 grupta da istatistiksel olarak anlamlı derecede daha iyi idi $(p<0,0001, p<0,0001, p<0,0001)$. Ortalama astigmat değerleri cerrahi öncesi LRI grubunda 2,92 $\pm 1,1,0 C C l$ gru-

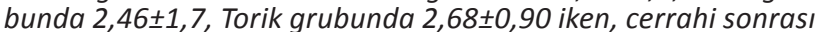

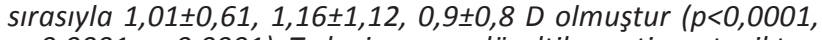
$p<0,0001, p<0,0001)$. Tedavi sonrası düzeltilen astigmat miktarı

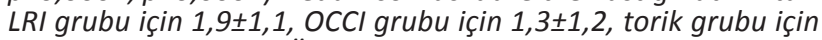
$1,78 \pm 0,90$ dioptridir. Üç grup arasındaki fark istatiksel olarak anlamlı değildir.

Sonuç: Tüm gruplarda postoperatif dönemde BCVA değerinde artış ve refraktif astigmatizmada azalma saptanmıştır. Refraktif astigmatizmada düzelme en çok LRI grubunda olmasına rağmen, gruplar arasında anlamlı fark yoktur.

Anahtar kelimeler: Astigmatizma, Limbal gevşetici insizyon, karşılıklı saydam korneal kesi, torik intraokular lens, katarakt

Received: 20.07 .2018

Accepted: 24.08 .2018

${ }^{1}$ Department of Ophthalmology, Kastamonu State Hospital, Kastamonu, Turkey

${ }^{2}$ Bascom Palmer Eye Institute, University of Miami, Miami, FL, USA.

${ }^{3}$ ünyagöz Sultanbeyli Hospital, İstanbul, Turkey

Corresponding author: Işılay Özsoy Koyun, Department of Ophthalmology, Kastamonu State Hospital, Kastamonu, Turkey

e-mail: drisilayozsoy@gmail.com

ORCID ID's:

I.Ö.K. 0000-0003-0101-1900 


\section{INTRODUCTION}

When correctly placed spherical lenses are used in cataract surgery, they do not result in any correction in the cylindrical value, whereas spherical error of the patient's lens should be corrected. There are studies reporting that the incidence of astigmatism at 1 diopter (D) and over is in the range of $36-45 \%$ in patients in whom cataract surgery was planned ${ }^{1,2}$. Today, we plan wave front-based customized surgeries, due to the visual symptoms caused by residual astigmatism. Modern cataract surgery has become refractive surgery, and the correction of the cylindrical value has gained importance ${ }^{3,4}$. During cataract surgery, there are many different treatment techniques for the correction of preexisting astigmatism. These include arcuate keratotomy, limbal relaxing incision (LRI), opposite clear corneal incision (OCCI), and toric intraocular lens (IOL) implantation ${ }^{5-13}$.

The clear corneal incision ( $\mathrm{CCl}$ ) has a local flattening effect, depending on the axis in which it is performed, as well as its width and structure ${ }^{14}$. When the preexisting astigmatism is higher than $1.00 \mathrm{D}$, most surgeons make the incision in the steep meridian to take advantage of the flattening effect of the incision ${ }^{15,16 .} \mathrm{OCCl}$ was first described by Lever and Dahan $^{10}$. In this procedure, one of the incisions is made on the steep corneal meridian, while the other is made symmetrically on the $180^{\circ}$ opposite site. The aim is to reinforce the flattening effect of the incision on the steep axis ${ }^{12,14,17,18}$. OCCI has been found to be more effective and safer than $\mathrm{CCl}$ alone in correcting preoperative corneal astigmatism ${ }^{12}$. LRI is a method based on the principle of flattening the steep axis with the "coupling" effect. According to Nichamin ${ }^{3}$, when LRI is combined with cataract surgery, it is safe and effective in correcting corneal astigmatism up to preoperative $3 \mathrm{D}$. There are many nomograms available to improve the predictability of the results ${ }^{19-21}$. With the advent of premium IOL technology, toric IOLs are also widely used for the correction of astigmatism in modern cataract surgery.

There are few studies in the literature comparing the methods of $\mathrm{OCCl}, \mathrm{LRI}$, and toric IOL implantation used to correct astigmatism in cataract surgery. We aimed to compare these three different methods in the present study.

\section{MATERIAL and METHOD}

In this retrospective study, the files of the patients who underwent phacoemulsification along with LRI, $\mathrm{OCCl}$, or toric IOL implantation due to corneal astigmatism at the hospital's ophthalmology department between March 2012 and June 2016 were screened retrospectively. Fifty-six eyes of 56 patients who met the study criteria were included in the study. Local ethics committee approval was obtained for the study. The ethical principles of the Helsinki declaration were followed during the research.

The patients were evaluated in three different groups. Those who underwent $\mathrm{LRI}, \mathrm{OCCl}$, and toric IOL implantation were classified as Groups 1, 2, and 3 , respectively.

Patients with corneal astigmatism above $1 \mathrm{D}$ were included in the study. Patients with irregular astigmatism, forme fruste keratoconus, corneal scar, phacodonesis, pseudoexfoliation syndrome, traumatic cataracts, and unstable capsular bag were not included.

Preoperatively, slit-lamp biomicroscopic examination was performed routinely in the patients, and corrected distance visual acuity (CDVA), manifest and cycloplegic refraction values, and intraocular pressures measured using a Goldman applanation tonometer were noted. The visual acuity values were converted from Snellen to logMAR.

Corneal topography was performed using Sirius topography (Costruzione Strumenti Oftalmici, Florence, Italy). The axial length was measured via Lenstar LS900 optical biometry (Haag Streit AG, Koeniz, Switzerland). The spherical lens power to be implanted was calculated with the formula appropriate for SRK/T or axial length. The cylindrical strength of the 
toric lens and axis to be implanted was determined using the Eyecryl Toric Calculator website (www.eyecryltoriccalculator.com) by entering the $\mathrm{K}$ values, $\mathrm{IOL}$ spheric power, surgically induced astigmatism (SIA) value, localization, and extend of the incision.

The standard SIA value was taken as $0.5 \mathrm{D}$ as the standard value. The corneas of all patients were marked preoperatively with a sterile marker pen at 0 and $180^{\circ}$ in the sitting position on the biomicroscope to avoid mistakes secondary to cyclotorsion. All operations were performed by the same surgeon (HB) under local (topical) anesthesia.

After local anesthesia, the patients' steep axis in all groups was marked by using a Whitman axis marker (Storz $\rightarrow$, Bausch and Lomb GMBH, Heidelberg, Germany). A phaco-incision was made on the steep axis with a 3-mm blade according to the keratometry values in three groups by taking the keratometry values of the patients as a reference. The operations were performed according to the standard phacoemulsification method.

Eyecryl ASHF600 (Biotech Vision Care, Ahmedabad, Gujarat, India) spherical IOLs were implanted in Groups 1 and 2 patients who underwent LRI and OCCI. Eyecryl ACTV TORIC (Biotech Vision Care) IOLs were implanted in Group 3 patients who underwent toric IOL implantation.

In Group 3 patients, the first imlantation was achieved by rotating the IOL clockwise before cleaning the viscoelastic material. After the viscoelastic material was removed with double hand irrigation/aspiration, the alignment axis marks were coupled with the reference marks on the $\mathrm{IOL}$ and its final position was given. The patients with the IOL axis rotation above $10^{\circ}$ were excluded from the study. Then, the main and side port incisions were closed with stroma hydration, and the wound leakage was checked. At this stage, Group 1 patients underwent LRI according to Nichamin's age and pachymetry-adjusted (NAPA) nomogram ${ }^{19}$. In contrast, the $\mathrm{OCCl}$ incision was performed in Group 2 patients at $180^{\circ}$ opposite to the
$\mathrm{CCl}$ made in the steep axis. Later, the wound leakage was controlled again. The operation was terminated by administering $0.05 \mathrm{cc}$ of moxifloxacin intracamerally. None of the patients required a corneal suture.

The patients were examined at postoperative 1 day, 1 week, 1 , and 6 months during the postoperative period in accordance with the general rules of our ophthalmology clinic. The patients' topographic measurements were taken preoperatively and at 6 months postoperatively. The patients were evaluated postoperatively via CDVA, keratometry, and topographic measurements. Preoperative and postoperative corneal astigmatism values were estimated using the vector analysis method. In the present study "Astigmatism Vector Analysis Program" was used to estimate the surgically induced astigmatism ${ }^{22}$.

The SPSS 20.0 Macintosh package program was used for the statistical analyses. The CDVAs were compared before and after surgery. Paired t-test was used to compare preoperative and postoperative values. To compare the measurements of the groups evaluated over time, the repeated-measures analysis of variance (ANOVA) test was used. Statistically, a pvalue $<0.05$ was considered significant.

\section{RESULTS}

Twenty-nine cases (48.2\%) were female and 27 $(51.8 \%)$ were male. The overall mean age was $60.66 \pm 13.50$ ( $\min : 29$, max: 84 ) years. The demographic characteristics of the patients participating in the study are summarized in Table 1.

There was no statistically significant difference between the groups' preoperative and postoperative visual acuity levels ( $p=0.529, p=0.967$, respectively). There was a significant difference between the preoperative and postoperative intragroup visual acuity levels $(p<0.01, p<0.01, p<0.01)$. The corrected visual acuities before surgery and at 6 months postoperatively are summarized in Table 2 . 
Table 1. Demographics of the patients included in to the study.

\begin{tabular}{|c|c|c|c|c|c|c|c|}
\hline & \multicolumn{2}{|c|}{ Group 1} & \multicolumn{2}{|c|}{ Group 2} & \multicolumn{2}{|c|}{ Group 3} & \multirow[t]{2}{*}{$p$ value } \\
\hline & Male & Female & Male & Female & Male & Female & \\
\hline Gender(n) & & 6 & 8 & 12 & 9 & 11 & $>0.05$ \\
\hline Mean Age $\pm S D$ & \multicolumn{2}{|c|}{$57.12 \pm 15.7$} & \multicolumn{2}{|c|}{$62.90 \pm 11.5$} & \multicolumn{2}{|c|}{$61.25 \pm 13.64$} & $>0.05$ \\
\hline
\end{tabular}

Group 1: LRI, Group 2: OCCI, Group 3: Toric IOL, SD: Standart Deviation

Table 2. Corrected distance visual acuity of the patients at preoperative period and postoperative sixth month.

\begin{tabular}{|c|c|c|c|}
\hline & $\begin{array}{l}\text { Preoperative } \\
\text { CDVA (Snellen) }\end{array}$ & $\begin{array}{l}\text { Postoperative } \\
\text { CDVA (Snellen) }\end{array}$ & P value \\
\hline Group 1 (LRI) & $\begin{array}{l}0.18 \pm 0.13 \\
(\operatorname{LogMAR}=1.009)\end{array}$ & $\begin{array}{l}0.68 \pm 0.25 \\
(\operatorname{LogMAR}=0.228)\end{array}$ & $P<0.01$ \\
\hline Group 2 (OCCI) & $\begin{array}{l}0.23 \pm 0.14 \\
(\operatorname{LogMAR}=0.73)\end{array}$ & $\begin{array}{l}0.70 \pm 0.25 \\
(\operatorname{LogMAR}=0.18)\end{array}$ & $P<0.01$ \\
\hline Group 3 (Toric) & $\begin{array}{l}0.22 \pm 0.13 \\
(\operatorname{LogMAR}=0.78)\end{array}$ & $\begin{array}{l}0.69 \pm 0.2 \\
(\operatorname{LogMAR}=0.17)\end{array}$ & $P<0.01$ \\
\hline
\end{tabular}

Table 3. Change in the refractive cylindric values.

\begin{tabular}{lllll}
\hline & $\begin{array}{l}\text { Preoperative } \\
\text { Refractive } \\
\text { Astigmatism(D) }\end{array}$ & $\begin{array}{l}\text { Postoperative } \\
\text { Refractive } \\
\text { Astigmatism(D) }\end{array}$ & $\begin{array}{l}\text { Preoperative- P value } \\
\text { Postoperative }\end{array}$ & $\begin{array}{l}\text { Refractive } \\
\text { Astigmatism } \\
\text { difference(D) }\end{array}$ \\
& & & \\
\hline Group 1 $2.92 \pm 1.1$ & $1.01 \pm 0.61$ & $1.9 \pm 1.1$ & $\mathrm{P}<0.01$ \\
Group 2 $2.46 \pm 1.7$ & $1.16 \pm 1.12$ & $1.3 \pm 1.2$ & $\mathrm{P}<0.01$ \\
Group 3 $2.68 \pm 0.90$ & $0.9 \pm 0.8$ & $1.78 \pm 0.90$ & $\mathrm{P}<0.01$ \\
Pvalue & 0.56 & 0.63 & 0.19 & \\
\hline
\end{tabular}

Group 1: LRI, Group 2: OCCI, Group 3: Toric, SIA: Surgically Induced Astigmatism

The changes in refractive cylindrical values before treatment and in the 6-month follow-up are summarized in Table 3. When the preoperative and postoperative refractive index values were analyzed statistically, a statistically significant change was observed in all three groups $(p<0.01, p<0.01, p<0.01)$. The maximum, and minimum changes in refractive cylindrical values were observed in the LRI, and $\mathrm{OCCl}$ groups, respectively. However, no statistically significant difference was found among the three groups as
Table 4. Preoperative-postoperative corneal astigmatism.

\begin{tabular}{lllll}
\hline & $\begin{array}{l}\text { Preoperative } \\
\text { Corneal } \\
\text { Astigmatism }\end{array}$ & $\begin{array}{l}\text { Postoperative } \\
\text { Corneal } \\
\text { Astigmatism }\end{array}$ & $\begin{array}{l}\text { Corneal } \\
\text { Astigmatism } \\
\text { Difference }\end{array}$ & P value \\
\hline Group 1 & $2.61 \pm 0.94$ & $1.16 \pm 0.55$ & $1.51 \pm 0.8$ & $P<0.01$ \\
Group 2 & $2.31 \pm 1.6$ & $1.11 \pm 1.1$ & $1.2 \pm 0.9$ & $P<0.01$ \\
Group 3 & $2.76 \pm 0.7$ & $2.53 \pm 0.6$ & $0.23 \pm 0.25$ & $P<0.01$ \\
\hline
\end{tabular}

Group 1: LRI, Group 2: OCCI, Group 3: Toric, SIA: Surgically Induced Astigmatism

for preoperative refractive cylindrical values, postoperative refractive cylindrical values, and pre-postoperative refractive cylindrical difference values $(p=0.563$, $p=0.639, p=0.193$, respectively). When the groups were compared dichotomously (LRI vs. OCCI, LRI vs. toric IOL and OCCI vs. toric IOL), no statistically significant difference was found in terms of these values.

A statistically significant reduction was observed in the corneal astigmatism in all three groups $(p<0.01$, $p<0.01, p<0.01$ ). The changes in topographic corneal astigmatism prior to treatment and at 6 months after treatment are summarized in Table 4.

When changes in surgically induced astigmatism were examined before treatment and in the 6-month control, the SIA values were found to be $2.24 \pm 1.3 \mathrm{D}$ in Group 1, 1.78 $\pm 0.91 \mathrm{D}$ in Group 2, and 0.26 $\pm 0.13 \mathrm{D}$ in Group 3 while; the difference among groups was found to be significant $(p<0.01)$. However, there was no statistically significant difference in terms of SIA between Groups 1 and $2(p=0.216)$. A statistically significant difference was found between Groups 1 and $3(p<0.01)$, as well as between Groups 2 and 3 $(p<0.01)$. The intergroup comparisons are summarized in Table 5. 
I. Ö. Koyun et al., Comparison of toric intraocular lens implantation, limbal relaxing incisions and opposite clear corneal incision for management of co-existing astigmatism on cataract surgery

Table 5. Comparison of surgically induced astigmatism between 3 groups.

\begin{tabular}{lll}
\hline & SIA difference & P value \\
\hline Group 1 vs Group 2 & 0.46 & 0.216 \\
Group 1 vs Group 3 & 1.98 & $<0.01$ \\
Group 2 vs Group 3 & 1.52 & $<0.01$ \\
\hline
\end{tabular}

Group 1: LRI, Group 2: OCCI, Group 3: Toric, SIA: Surgically Induced Astigmatism

\section{DISCUSSION}

Residual astigmatism after cataract surgery is the most important reason for using eyeglasses. Thus, although the correction of astigmatism is necessary in patients with cataract to provide emmetropia and spectacle independence, its use is still limited. Therefore, it is important to popularize and improve the treatment modalities for correcting astigmatism in cataract surgery. Some of these methods include $\mathrm{OCCl}, \mathrm{LRI}$, and toric IOLs.

The mean astigmatism correction value was found to be statistically higher in the studies comparing $\mathrm{OCCl}$ with the group undergoing $\mathrm{CCl}$ alone ${ }^{17,18,23}$. The mean astigmatism correction in the studies conducted with $\mathrm{OCCl}$ was in the range of 1.07-2.06 $\mathrm{D}^{10,17,18,23}$. In our study, the mean corneal astigmatism correction in Group 2 (OCCl group) was $1.2 \pm 0.9 \mathrm{D}$. The mean SIA was in the range of 1.66-2.25 $\mathrm{D}^{10,11,17,18,24}$. The SIA value was $1.78 \pm 0.91 \mathrm{D}$ in the OCCl group of our study. This difference among studies may have been caused by the preoperative mean astigmatism values, length of incision, or difference in localization. Mendicute et al. compared toric intraocular lenses with $\mathrm{OCCl}$, and a significant reduction was detected in the postoperative refractive astigmatism value in both groups ${ }^{14}$. A significant reduction was noted in the residual refractive cylindrical values in the toric IOL group compared with the $\mathrm{OCCl}$ group in the study by Maedel et al., in which the toric IOL and OCCI were compared ${ }^{25}$ In our study, the reduction in refractive astigmatism was $1.78 \pm 0.90 \mathrm{D}$ in the toric $\mathrm{IOL}$ group and 1.3 $\pm 1.2 \mathrm{D}$ in the $\mathrm{OCCl}$ group. A statistically significant decrease was present in both groups, whereas there was no statistically significant difference between the two groups in terms of the residual refractive cylindrical values $(p=0.39)$. Although the amount of residual refractive astigmatism was found to be numerically low in the toric IOL group, we think that the reason for the absence of a statistically significant difference in both groups was due to the inadequate number of patients. Since the correction mechanism of astigmatism in toric IOL did not involve the corneal route, postoperative corneal astigmatism was found to be significantly higher than it was in the OCCl group. The SIA value was $0.26 \pm 0.13 \mathrm{D}$ in the toric IOL group while it was $1.78 \pm 0.91 \mathrm{D}$ in the LRI group $(p<0.01)$.

Another method for correcting corneal astigmatism is limbal relaxing incision. A significant increase was observed when preoperative and postoperative CDVAs were compared in Group 1 (LRI), whereas no significant difference was detected when compared with the other two groups. This increase in visual acuity in the LRI group indicates that any corneal aberration that may be caused by LRI does not affect the visual acuity. The SIA value of the LRI group calculated at 6 months was $1.50 \mathrm{D}$ in the study by Carvalho et al. ${ }^{26}$, while it was $1.47 \mathrm{D}$ in the study by Budak et al., in which they performed LRI using the modified Gills nomogram ${ }^{8}$. The SIA value was $1.21 \mathrm{D}$ in the group that underwent temporal incision along with LRI in the study by Kaufman et al., while the SIA value of Group 1 in our study at 6 months was $2.24 \pm 1.3 D^{27}$. One reason for these different values among studies may be due to using different nomograms. The nomograms in an average patient give the expected result, but the expected results may not be achieved due to the elasticity properties of the cornea and scar formation after surgery. When our study is to be compared with other studies, we suggest that the reason for the higher SIA values in our research is the relatively low number of patients and short followup period. Another reason for the differences among the LRI groups may be the localizations of CCls. Although the astigmatic effect of temporal incisions is said to be minimal, it is not neutral. This situation can cause diversity in the LRI group as the total effect is compared in the studies. In our research, the 
preoperative mean value of topographic astigmatism was 2.61 $\pm 0.94 \mathrm{D}$ in Group 1, while the postoperative mean value regressed to $1.16 \pm 0.55 \mathrm{D}$. The inability to attain the targeted astigmatism value in LRIs, is due to, inadequate correction of astigmatism which is not an uncommon practice $8,9,26,28,29$. This correction rate was $24 \%$ in the study by Carvalho et al. ${ }^{26}$, while it was reported to be $75 \%$ in the study by Budak et al. ${ }^{8}$. The reason for this incomplete correction may be mismarking, error in the calibration of the blade, or making the incision at a wrong depth because of an oblique but not perpendicular position of the blade to the limbus ${ }^{6}$. Performing LRI prior to the implantation of IOL can also cause the incision to be superficial. Performing LRI after phacoemulsification and IOL implantation can prevent the incision from being superficial due to balancing intraocular pressure owing to the balanced saline solution and viscoelastic material ${ }^{26}$.

Toric lenses, another alternative to cataract surgery in the correction of astigmatism, were designed by Shimizu et al. ${ }^{30}$ in 1992; however, the first toric IOL lenses caused a high degree of rotation after implantation. With advancing technology, the use of a toric IOL with increased rotational stability has become one of the most important alternatives for correcting preoperative corneal astigmatism in cataract surgery. In our study, CDVA showed a significant postoperative increase in the toric IOL and LRI groups $(p<0.01)$, whereas no significant difference was observed among the groups in terms of preoperative and postoperative CDVA. Similar results were found in other studies comparing toric $\operatorname{IOL}$ and $\mathrm{LRI}^{28,29,31,32}$. The relatively low CDVA values compared with other studies were likely caused by the fact that patients with low visual acuity due to retinal problems decrase the mean value. However, visual acuity measurement alone is not a reliable parameter-it depends on variable factors. For this reason, it may be more valuable to evaluate the difference between CDVA and uncorrected visual acuity (UCVA) when comparing astigmatism correction methods ${ }^{33}$. In our study, the rate of reduction in refractive astigmatism was $68 \%$ in the toric IOL group and $65 \%$ in the LRI group. Postoperative residual refractive astigmatism was $0.9 \pm 0.8 \mathrm{D}$ in the toric $\mathrm{IOL}$ group, while it was found to be $1.01 \pm 0.61 \mathrm{D}$ in the LRI group. There was no significant difference between the two groups $(p=0.62)$.

The mean rate of reduction in refractory astigmatism was $67 \%$ in the toric IOL, and $40 \%$ in the LRI groups in the study reported by Mingo-Botin et al. ${ }^{31}$ residual astigmatism was significantly lower in the toric IOL group compared with the LRI group. The rate of reduction in refractive astigmatism was $64 \%$ in the toric IOL group and $32 \%$ in the LRI group in the study by Muftuoglu et al. In this study, the residual astigmatism was significantly lower at the postoperative 1. and 6. months in the toric IOL group ${ }^{28}$. Lam et al. ${ }^{32}$ observed a significant reduction in refractive astigmatism in the toric and LRI groups, whereas they detected no significant difference between the two groups. Gangwani et al. ${ }^{33}$ also reported that the residual refractive astigmatism at 3 months was $0.45 \pm 0.49 \mathrm{D}$ in the multifocal toric IOL group, while it was $0.72 \pm 0.61$ $D$ in the multifocal LRI group ( $p=0.046)$. Moreover, in the study by Hirnschall et al..$^{29}$ the rate of residual refractive astigmatism under $1 \mathrm{D}$ was found to be $96 \%$ in the toric IOL group and $84 \%$ in the LRI group. Liu et al. ${ }^{34}$ reported that the LRI and toric IOL techniques had similar effects on preoperative low astigmatism, although toric IOL was found to be more effective in patients with high preoperative astigmatism. As understood from our study results, the preoperative astigmatism value and angle, and position of the incision are important factors affecting the outcome of cataract surgery.

The amount of residual astigmatism in the toric IOL group depends on numerous factors. The incorrect measurement of preoperative corneal astigmatism, incorrect marking of the axis, mislabeling the degree of toric IOL, deeper or shallower depth of postoperative anterior chamber than expected, misplacement of $\mathrm{IOL}$, and tilted or rotated $\mathrm{IOL}$ are among some of these causes ${ }^{29}$. Correct corneal astigmatism measurements should be obtained prior to the implantation of toric IOL for an effective astigmatism 
correction. Neglect of posterior corneal involvement may cause under or overestimation of the diopter of astigmatism. In our study, preoperative and postoperative corneal astigmatism values were taken as a basis while calculating the SIA value in the toric IOL group. For this reason, SIA was $0.26 \mathrm{D}$ in the toric IOL group, while it was calculated to be $2.24 \mathrm{D}$ in the LRI group. In the study by Muftuoglu et al., the SIA value was 1.67 at postoperative 6 months in the toric IOL group, while it was $0.92 \pm 1.96$ in the LRI group ${ }^{28}$. In both groups, the SIA values were found to be lower than the target-induced astigmatism (TIA) value, and the magnitude of error (ME), which is the difference between these two values, was found to be higher in the LRI group. In the study by Hirnschall et al. ${ }^{29}$, the SIA value was $1.74 \pm 0.64$ in the toric IOL group, while it was found to be $1.27 \pm 0.76$ in the LRI group; the difference between the two groups was statistically significant $(p=0.042)$. In the study by Gangwani et al. ${ }^{33}$, the SIA value was $1.76 \pm 0.47$ in the toric IOL group and $1.56 \pm 0.63$ in the LRI group. The vectorial decrease in astigmatism in the toric IOL group was statistically significant compared with that of the LRI group ( $p=0.042$ ). In these studies, the specific reason for the difference in SIA values in the toric IOL group was related to consideration of postoperative refractive astigmatism values rather than postoperative corneal astigmatism.

Many studies have reported a regression in the corneal astigmatism during postoperative follow-up of patients undergoing LRI 27-29,31,34. Therefore, long-term follow-up results are important in these patients. Since our study had a retrospective design, the amount of regression in corneal astigmatism could not be calculated because the patients were lost to follow up. This is one of the limitations of the study. In Mingo-Botin et al.'s research, there was no difference between the two groups in the measurements made without glare in contrast sensitivity assessment, while mesopic contrast sensitivity was found to be better in the toric IOL group in the measurements with glare. Therefore, toric IOL may be preferred in elderly patients, since glare creates more of a disturbance at night.
In the toric IOL group, spectacle-independence was found to be three times higher than LRI, and this result was consistent with those of previous studies $^{31}$. Lam et al. reported a significant postoperative increase in contrast sensitivity observed in both groups; no difference was found between the two groups. In our study, although there was no statistically significant difference, the need for wearing eyeglasses decreased in the toric IOL group, whereas it was not affected in the LRI group.

Although no difference was observed among the groups in terms of UCVA, the lesser need for glasses in the toric IOL group can be explained by the fact that the difference in high-order aberrations between two groups reduced the visual quality. Gangwani et al. investigated halo, glare, and the need for wearing glasses in their survey, and they did not report a statistical difference between the multifocal toric and multifocal LRI groups ${ }^{33}$. In our study, contrast sensitivity and the need for eyeglasses were not considered, and this was another limitation of our study.

A study comparing LRI with OCCl has not yet been published in the literature. Thus, our study is of value since it compared these two techniques. When the LRI group was compared with $\mathrm{OCCl}$, postoperative CDVA and SIA were higher and the change in refractive astigmatism and residual astigmatism values were lower in the LRI group. The reason for the lack of statistical significance between these results may have been the limited number of patients (16 patients vs. 20 patients) in our study. When each of the three groups was examined in relation to these findings, the advantages and disadvantages of the different approaches are evident. Although $\mathrm{OCCl}$ is a simple, and safe method for correcting corneal astigmatism in cataract surgeries, and it does not require additional surgical equipment and experience compared with astigmatic keratotomies, it is risky in terms of wound site leakage. For this reason, the leakage should be completely controlled in the early postoperative period. The OCCI technique can be used for the correction of mild-to-moderate astigmatism in cataract surgery. However, there is a 
need to develop nomograms showing the association of the incision's width, length, and distance to the limbus with astigmatism. LRI is easier and safer than corneal incisions, since it causes less glare, less torsional diplopia, and less overcorrection, and less fluctuation in refraction because of the preservation of the optical quality of the cornea due to its distant localization from the central optic zone. However, its perioperative complications include suture and perforation due to wound dehiscence ${ }^{35}$. In the postoperative period, dry eye and foreign body sensation may develop in patients ${ }^{28}$. Although it is a relatively less costly technique for correcting low and moderate astigmatism in cataract surgery compared with the toric IOLs, the disadvantages of this technique include low predictability and high variability, as well as the probability of development of regression in the postoperative period. Toric IOL can correct astigmatism at higher degrees, and it is considered more effective and predictable than the other methods. However, it is disadvantageous in terms of high cost, difficulty in adjusting the toric IOL axis, and rotational instability ${ }^{13,36}$.

\section{CONCLUSION}

An increase in the CDVA values and reduction in refractive astigmatism were achieved in all three methods postoperatively. Although the most prominent improvement in refractive astigmatism occurred in the LRI group, there was no significant difference between the groups. We suggest that there is a need for conduction of larger scale studies with randomized patient groups to improve all these methods and find the optimal treatment method that can be applied to the patient.

\section{REFERENCES}

1. De Bernardo M, Zeppa L, Cennamo M, laccarino S, Zeppa L, Rosa N. Prevalence of corneal astigmatism before cataract surgery in Caucasian patients. Eur J Ophthalmol. 2014 JulAug;24(4):494-500. https://doi.org/10.5301/ejo.5000415

2. Guan Z, Yuan F, Yuan YZ, Niu WR. Analysis of corneal astigmatism in cataract surgery candidates at a teaching hospital in Shanghai, China. J Cataract Refract Surg. 2012
Nov;38(11):1970-7.

https://doi.org/10.1016/j.jcrs.2012.07.025

3. Nichamin LD. Astigmatism control. Ophthalmol Clin North Am. 2006 Dec;19(4):485-93.

4. Gills JP. Treating astigmatism at the time of cataract surgery. Curr Opin Ophthalmol. 2002;13(1):2-6. https://doi.org/10.1097/00055735-200202000-00002

5. Inoue T, Maeda N, Sasaki K, Watanabe H, Inoue Y, Nishida $\mathrm{K}$, et al. Factors that influence the surgical effects of astigmatic keratotomy after cataract surgery. Ophthalmology 2001;108:1269-74. https://doi.org/10.1016/S0161-6420(01)00629-7

6. Akura J, Matsuura K, Hatta S, Otsuka K, Kaneda S. A new concept for the correction of astigmatism: full-arc, depth-dependent astigmatic keratotomy. Ophthalmology. 2000;107:95104.

https://doi.org/10.1016/S0161-6420(99)00021-4

7. Müller-Jensen K, Fischer P, Siepe U. Limbal relaxing incisions to correct astigmatism in clear corneal cataract surgery. J Refract Surg. 1999 Sep-Oct;15(5):586-9.

8. Budak K, Friedman NJ, Koch DD. Limbal relaxing incisions with cataract surgery. J Cataract Refract Surg. 1998 Apr;24(4):503-8. https://doi.org/10.1016/S0886-3350(98)80292-7

9. Bayramlar H, Dağlioğlu MC, Borazan M. Limbal relaxing incisions for primary mixed astigmatism and mixed astigmatism after cataract surgery. J Cataract Refract Surg. 2003 Apr;29(4):723-8. https://doi.org/10.1016/S0886-3350(02)01821-7

10. Lever J, Dahan E. Opposite clear corneal incisions to correct pre-existing astigmatism in cataract surgery. J Cataract Refract Surg. 2000 Jun;26(6):803-5.

https://doi.org/10.1016/S0886-3350(00)00378-3

11. Tadros A, Habib M, Tejwani D, Von Lany H, Thomas P. Opposite clear corneal incisions on the steep meridian in phacoemulsification: early effects on the cornea. J Cataract Refract Surg. 2004 Feb;30(2):414-7. https://doi.org/10.1016/S0886-3350(03)00649-7

12. Khokhar S, Lohiya P, Murugiesan V, Panda A. Corneal astigmatism correction with opposite clear corneal incisions or single clear corneal incision: comparative analysis. J Cataract Refract Surg. 2006 Sep;32(9):1432-7. https://doi.org/10.1016/j.jcrs.2006.04.010

13. Visser N, Bauer NJ, Nuijts RM. Toric intraocular lenses: historical overview, patient selection, IOL calculation, surgical techniques, clinical outcomes, and complications. J Cataract Refract Surg. 2013 Apr;39(4):624-37. https://doi.org/10.1016/j.jcrs.2013.02.020

14. Mendicute J, Irigoyen C, Ruiz M, Illarramendi I, Ferrer-Blasco T, Montés-Micó R. Toric intraocular lens versus opposite clear corneal incisions to correct astigmatism in eyes having cataract surgery. J Cataract Refract Surg. 2009 Mar;35(3):451-8. https://doi.org/10.1016/j.jcrs.2008.11.043

15. Pfleger T, Skorpik C, Menapace R, et al. Long-term course of induced astigmatism after clear corneal incision cataract surgery. J Cataract Refract Surg. 1996;22:72-7. https://doi.org/10.1016/S0886-3350(96)80273-2

16. Nielsen PJ. Prospective evaluation of surgically induced astigmatism and astigmatic keratotomy effects of various self-sealing small incisions. J Cataract Refract Surg. 1995;21:43-8. https://doi.org/10.1016/S0886-3350(13)80478-6

17. Ben Simon GJ, Desatnik H. Correction of pre-existing astigmatism during cataract surgery: comparison between the effects of opposite clear corneal incisions and a single clear 
I. Ö. Koyun et al., Comparison of toric intraocular lens implantation, limbal relaxing incisions and opposite clear corneal incision for management of co-existing astigmatism on cataract surgery

corneal incision. Graefes Arch Clin Exp Ophthalmol. 2005 Apr;243(4):321-6. https://doi.org/10.1007/s00417-004-1035-3

18. Bazzazi N, Barazandeh B, Kashani M, Rasouli M. Opposite Clear Corneal Incisions versus Steep Meridian Incision Phacoemulsification for Correction of Pre-existing Astigmatism. J Ophthalmic Vis Res. 2008 Apr;3(2):87-90.

19. Nichamin LD. Modified astigmatism correction nomogram. J Refract Surg. 2008 Jun;24(6):562-3.

20. Gills JP. A complete guide to astigmatism management. Thorofare, NJ:SLACK Incorporated; 2003.

21. Lindstrom RL, Lindquist TD. Surgical correction of postoperative astigmatism. Cornea. 1988;7(2):138-48. https://doi.org/10.1097/00003226-198802000-00010

22. Eğrilmez S, Dalkılıç G, Yagci A. Vector analysis software on analyzing astigmatism. Turk J Ophtalmol. 2003;33:404-16.

23. Razmjoo H, Koosha N, Vaezi MH, Rahimi B, Peyman A. Corneal astigmatism change and wavefront aberration evaluation after cataract surgery: "Single" versus paired opposite" clear corneal incisions. Adv Biomed Res. 2014 Aug 19;3:163. https://doi.org/10.4103/2277-9175.139126

24. Qammar A, Mullaney P. Paired opposite clear corneal incisions to correct preexisting astigmatism in cataract patients. J Cataract Refract Surg. 2005;31:1167-70. https://doi.org/10.1016/j.jcrs.2004.11.053

25. Maedel S, Hirnschall N, Chen YA, Findl O. Rotational performance and corneal astigmatism correction during cataract surgery: aspheric toric intraocular lens versus aspheric nontoric intraocular lens with opposite clear corneal incision. J Cataract Refract Surg. 2014 Aug;40(8):1355-62. https://doi.org/10.1016/j.jcrs.2013.11.039

26. Carvalho MJ, Suzuki SH, Freitas LL, Branco BC, Schor P, Lima AL. Limbal relaxing incisions to correct corneal astigmatism during phacoemulsification. J Refract Surg. 2007 May;23(5):499-504.

27. Kaufmann C, Peter J, Ooi K, Phipps S, Cooper P, Goggin M; Queen Elizabeth Astigmatism Study Group. Limbal relaxing incisions versus on-axis incisions to reduce corneal astigmatism at the time of cataract surgery. J Cataract Refract Surg. 2005 Dec;31(12):2261-5. https://doi.org/10.1016/j.jcrs.2005.08.046

28. Muftuoglu IK, Aydin Akova Y, Aksoy S, Unsal E. Comparison of astigmatism correction using either peripheral corneal relaxing incisions or toric intraocular lenses. Eur J Ophthalmol.
2016 May-Jun;26(3):236-41. https://doi.org/10.5301/ejo.5000690

29. Hirnschall N, Gangwani V, Crnej A, Koshy J, Maurino V, Findl O. Correction of moderate corneal astigmatism during cataract surgery: toric intraocular lens versus peripheral corneal relaxing incisions. J Cataract Refract Surg. 2014 Mar;40(3):35461. https://doi.org/10.1016/j.jcrs.2013.08.049

30. Shimizu K, Misawa A, Suzuki Y. Toric intraocular lenses: correcting astigmatism while controlling axis shift. J Cataract Refract Surg. 1994;20:523-6. https://doi.org/10.1016/S0886-3350(13)80232-5

31. Mingo-Botín D, Mu-oz-Negrete FJ, Won Kim HR, Morcillo-Laiz $\mathrm{R}$, Rebolleda G, Oblanca N. Comparison of toric intraocular lenses and peripheral corneal relaxing incisions to treat astigmatism during cataract surgery. J Cataract Refract Surg. 2010 Oct;36(10):1700-8. https://doi.org/10.1016/j.jcrs.2010.04.043

32. Lam DK, Chow VW, Ye C, Ng PK, Wang Z, Jhanji V. Comparative evaluation of aspheric toric intraocular lens implantation and limbal relaxing incisions in eyes with cataracts and $\leq 3$ dioptres of astigmatism. Br J Ophthalmol. 2016 Feb;100(2):25862. https://doi.org/10.1136/bjophthalmol-2014-306587

33. Gangwani V, Hirnschall N, Findl O, Maurino V. Multifocal toric intraocular lenses versus multifocal intraocular lenses combined with peripheral corneal relaxing incisions to correct moderate astigmatism. J Cataract Refract Surg. 2014 Oct;40(10):1625-32.

https://doi.org/10.1016/j.jcrs.2014.01.037

34. Liu $\mathrm{Z}$ et al. Toric intraocular lens vs peripheral corneal relaxing incisions to correct astigmatism in eyes undergoing cataract surgery. Eye Sci. 2014 Dec;29(4):198-203.

35. Sharma BR, Kumar A. Preliminary experiences with limbal relaxing incision for treatment of astigmatism during phacoemulslfication. Nepal J Ophthalmol. 2009 JulDec;1(2):90-4.

36. Holland E, Lane S, Horn JD, Ernest P, Arleo R, Miller KM. The AcrySof Toric intraocular lens in subjects with cataracts and corneal astigmatism: a randomized, subject-masked, parallelgroup, 1-year study. Ophthalmology. 2010 Nov;117(11):210411. https://doi.org/10.1016/j.ophtha.2010.07.033 